\title{
Kepentingan Aktor : Korupsi Usulan Perubahan Peta Lahan Dalam Kebijakan Revisi Alih Fungsi Hutan Di Provinsi Riau Tahun 2014
}

\author{
${ }^{1}$ Hazqon Fuadi Nasution, ${ }^{2}$ Julian Aldrin Pasha \\ ${ }^{12}$ Universitas Indonesia \\ e-mail: hafunasution@gmail.com
}

\begin{abstract}
Abstrak
Penelitian ini membahas mengenai kepentingan aktor dalam fenomena korupsi pada kasus Annas Ma'amun selaku eks Gubernur Riau terkait revisi alih fungsi hutan di Provinsi Riau. Beberapa studi menjelaskan korupsi politik sarat melibatkan kekuasaan sebagai bagian dari kunci strategi dan terdapat interaksi yang membangun pola hubungan dari kepentingan kolektif hingga intra-group masih melihat bahwa korupsi politik ini upaya secara sistemik untuk mendapatkan keuntungan materi yang berlebih maupun perlindungan bisnis tertentu. Penelitian ini bertujuan membahas sejauh mana interaksi tersebut memiliki kepentingan terselubung dan memberikan pengaruh sehingga terjadi tindakan korupsi. Dengan menggunakan metode kualitatif yaitu studi pustaka dan mengumpulkan data melalui wawancara mendalam. Peneliti berargumen bahwa opini yang dibangun seolah-olah masalah korupsi seringkali dianggap selesai jika seorang pelaku korupsi sudah ditangkap terutama yang berkuasa ikut terlibat. Penelitian ini sebagian besar merespon kebijakan revisi alih fungsi hutan yang kaitannya telah terjadi tindakan korupsi pada proses usulan perubahan peta kawasan hutan Provinsi Riau. Bahwa sebagian usulan perubahan peta lahan ini berkorelasi dengan kepentingan pembisnis besar terutama bisnis perkebunan kelapa sawit yang dominan di Provinsi Riau. Revisi tersebut walaupun dasarnya memberi mandat demi kepentingan luas masyarakat Riau yang lahannya belum terakomodir tetapi menjadi celah penyelewangan oleh oknum pejabat dan segelitir aktor berkepentingan. Temuannya, pertama korupsi yang ditopang oleh jaringan elit politik dan bisnis, kontestasi aktor dalam perubahan kawasan hutan terkait rancangan rencana tata ruang wilayah (RTRW) Provinsi Riau dan kepentingan electoral yang berkelin dan dengan kepentingan penguasaan sumber daya alam (SDA).
\end{abstract}

Kata Kunci: Korupsi, Korupsi politik, Revisi, Interaksi

\section{Abstract}

This research discusses the interests of actors in the phenomenon of corruption in the case of Annas Ma'amun as the ex-Governor of Riau regarding the revision of forest function conversion in Riau Province. Several studies explain that political corruption involves power as part of a key strategy and there are interactions that build relationship patterns from collective to intra-group interests still sees that political corruption is a systemic attempt to gain excess material benefits and protect certain businesses. This study aims to discuss the extent to which these interactions have hidden interests and have an effect on corruption. By using qualitative methods, namely literature study and collecting data through in-depth interviews. The researcher argues that opinions that are built as if the problem of corruption are often considered resolved if a corruption actor has been arrested, especially those in power who are involved. Most of this research responds to the revised forest function conversion policy, which is related to corruption in the proposed process for changing the forest area map of the Riau Province. Whereas some of the proposed changes to the land map are correlated with the interests of big businessmen, especially the dominant oil palm plantation business in Riau Province. Even though the revision basically mandates the broad interests of the Riau community whose land has not been accommodated, it is a gap between officials and a handful of interested actors. The findings, first, are corruption supported by a network of political and business elites, actor contestation in forest area changes related to the spatial planning plan (RT RW) of Riau Province and electoral interests that are linked and with the interests of controlling natural resources (SDA).

Keywords: Corruption, Political Corruption, Revision, Interaction 


\section{PENDAHULUAN}

Provinsi Riau merupakan salah satu provinsi yang terkena dampak kerusakan lingkungan atau krisis ekosistem akibat pembukaan lahan dan menyebabkan climate change. Hal ini merespon kerugian maupun dampak dari pembukaan lahan untuk bisnis tertentu. Salah satu faktornya adalah akibat dari pemanfaatan produksi lahan secara massif serta tidak mengedepankan stabilitas lingkungan. Fenomena yang terjadi menunjukkan ada kepentingan dalam suatu proses tata ruang melibatkan pihak swasta (Myers \& Ardiansyah, 2015). Adapun ini tidak terlepas dari kawasan hutan di Indonesia yang banyak dipengaruhi oleh kepentingan para pelaku ekonomi (Maryudi, 2015).

Bahwa ditemukan alokasi penggunaan lahan dalam tata ruang provinsi dan terdapat fakta adanya permasalahan dalam usulan revisi RTRW terkait dengan mekanis meperubahan kawasan hutan (Syahadat \& Subarudi, 2012:131-143).Seperti kasus pengajuan revisi poin tertentu dalam kebijakan RTRW Provinsi Riau adalah bukti nyata dalam meletakan kepentingan tersebut, sehingga revisi ini pihak korporasi berusaha untuk melakukan suap kepada pihak pemerintah daerah dan agar bisa meloloskan proyek terkait pembukaan lahan (acch.kpk.go.id). Proses revisi tersebut menjelaskan pada poin pelepasan kawan hutan dan lahan yang belum terakomodir yang diusulkan oleh pemerintah daerah natinya. Secara tidak langsung pembahasan dan pengambilan keputusan terkait revisi kebijakan ada tarik menarik kepentingan.

Dalam kontek spolitik terkait pengambilan keputusan sebuah kebijakan di tingkat lokal, yaitu di Provinsi Riau adanya aliran dana atau pemberian insentif yang terjadi antara pihak ketiga sebagai perantara kepada Kepala Daerah (Senarai.or.id). Dengan bertujuan untuk mempermudah proses revisi alih fungsi hutan dalam pembahasan RTRW di tingkat provinsi. Hal tersebut secara tidak langsung membuktikan bahwa persoalan tata ruang di Indonesia masih sangat kompleks (Brockhaus et al., 2012), terutama yang terjadi di Provinsi Riau hingga saat ini.

Fenomena ini setidaknya memberikan gambaran korupsi politik, dimana pemerintah selaku pejabat publik memiliki wewenang dan pengaruh serta bertanggung jawab atas keputusan politik yang diambil pada setiap kebijakan. Secara tidak langsung juga melibatkan pihak-pihak pemerintahan daerah, korporat,dan stakeholder ataupun aktor lainnya yang keseluruhan memiliki kepentigan terhadap kebijakan tata ruang. Dalam bahasa lainnya aktor dapat disebut juga sebagai stakeholder (Barrow et al., 2002).

Della Porta dan Vannucci (2012)melihat bahwa korupsi politik merupakan ancaman signifikan terhadap stabilitas lembaga-lembaga demokratis dan untuk keberhasilan demokratisasi. Argumennya korupsi politik merupakan pola korupsi yang sistemik, dimana tidak hanya terbatas pada negara-negara berkembang saja atau kebanyakan dibayangkan oleh orang. Korupsi itu sendiri seperti menemukan tanah subur di dalam organisasi publik di beberapa negara demokrasi maju. Di karenakan kuat, dapat berkembang sendiri dan dapat dengan mudah menyebar karena korupsi ini mendelegitimasi badan publik dan mengingat tingginya biaya ekonomi dan politik yang ditimbulkannya ataupun termasuk biaya melawannya.

Sedangkan Arnold Heidenheimer (1970) menjelaskan konsep korupsi politik dalam tiga ranah, yaitu public office-centered, public interest-centered dan market definitions. Dalam definisinya, Heidenheimer menyatakan bahwa korupsi politik merupakan sebuah tindakan di luar legalitas oleh otoritas pemangku kekuasaan dalam rangka mengambil keuntungan dari kekuasaan yang dipegangnya (public office interest) yang mengakibatkan tereduksinya kepentingan publik (public interest-centered) dan ditujukan untuk memaksimalkan keuntungan ekonomi (market definitions). Bahwa proposisi dari masing-masing pendekatan tersebut menggambarkan dinamika korupsi politik

Penelitian ini akan mengupas dan menganalisa fenomena korupsi politik hingga bisnis saling berhubungan. Menurut Ackerman (2006), terkait korupsi bisnis politik merupakan gambaran hubungan antara negara dan sector swasta. Kadang-kadang petugas negara yang menjadi pelaku dominan, kadangkandang pelaku swasta yang paling berkuasa. Kekuasaan tawar-menawar relative antara kelompok ini menentukan dampak keseluruhan korupsi terhadap masyarakat dan pembagian keuntungan antara yang 
disuap dengan penyogok. Hal ini biasanya dimainkan dalam formulasi sebuah kebijakan yang menguntungkan beberapa kalangan atau group.

Berdasarkan proses pengajuan izin revisi oleh Kepala Daerah, ada dugaan pola-pola kepentingan dalam upaya manipulasi kebijakan yang menguntungkan pihak tertentu ketika pembahasan RTRW sedang berjalan. Hal ini terbukti dari adanya pemberian insentif oleh Gulat Medali Emas Manurung selaku Ketua Apkasindo (Asosiasi Petani Kelapa Sawit Indonesia) Provinsi Riau kepada Gubernur Riau Annas Ma'amun saat itu sehingga terjadi OTT yang dilakukan oleh KPK(jikalahari.or.id, 2020).

Pada umumnya, kebijakan tata ruang tidak memberikan ijin dengan mudah kepada swasta/korporasi. Terutama yang tidak taat aturan dan apalagi sampai mengancam maupun menyebabkan kerusakan lingkungan. Akan tetapi pada studi kasus yang akan diteliti oleh penulis, yaitu ada temuan korupsi terkait usulan perubahan peta lahan dalam proses pembahasan revisi alih fungsi hutan yang nanti tertuang di dokumen Peranturan Daerah (PERDA) RTRW Provinsi Riau. Kemudian korupsi tersebut melibatkan mantan Gubernur Riau Annas Ma'amun pada tahun 2014 sebagai pemberi usulan perubahan peta lahan dan ada indikasi terlibatnya berbagai korporasi atas pemberian insentif atau suap. Makarelasi hubungan antara elit pemerintah/birokrat, politisi dan swasta/korporasi merangkum sebuah hipotesa awal mula rangkaian kepentingan itu terbentuk.

\section{METODE}

Metode dalam penelitian ini akan menggunakan pendekatan kualitatif. Menurut Gogdan dan Guba pendekatan kualitatif adalah prosedur penelitian yang menghasilkan data dekskriptif, yaitu data yang dikumpulkan berupa kata-kata, gambar dan bukan sebatas/sekedar angka-angka (Lexi, 2006). Berdasarkan jenis penelitian tersebut maka penelitian ini bersifat deskriptif, yakni mengemukakan fakta tentang pola korupsi politik yang terlibat dalam proses pengajuan dan pembahasan revisi alih fungsi hutan dalam rancangan Rencana Tata Ruang Wilayah (RTRW) Provinsi Riau.

Jenis penelitian ini adalah studi kasus, sesuai sifat dan karakter permasalahan yang diangkat dalam penelitian ini.Maka penelitian ini diperoleh melalui wawancara mendalam (depth interview) kepada narasumber yang memiliki keterkaitan dengan masalah penelitian. Narasumber dipilih dengan sengaja sesuai kapasitasya dan penuh perencanaan (purpose full select) (Creswell, 2016).

\section{HASIL DAN PEMBAHASAN}

Terbitnya Surat Keputusan (SK) Menteri Kehutanan Republik Nomor SK.673/Menhut-II/2014 Tentang Perubahan Peruntukan Kawasan Hutan Menjadi Bukan Kawasan Hutan sehingga menimbulkan kabar baik tapi sekaligus kekhawatiran. Hal ini bagaikan dua sisi mata uang koin yang berbeda dan seakan memberikan kemudahan atau kesulitan. Seperti SK 673 ini menjadi opsi usulan dalam merevisi kembali kawasan hutan dan lahan untuk dapat merekomendasikan aspirasi daerah tetapi disatu sisi angin segar untuk pemilik lahan perkebunan terutama korporasi besar karena tidak akan mudah atau sulit mengaturnya.

Pada dasarnya penerbitan SK 673 Tahun 2014 tidak serta muncul tanpa suatu situasi politik yang menyertainya. Dikarenakan secara tidak langsung membuka kesempatan kepada masyarakat yang ingin mengajukan permohonan revisi bila ada kawasan atau lahan belum terakomodir melalui pemerintah daerah. Hal tersebut dimanfaatkan oleh sejumlah korporasi untuk mengurus ijin usahanya.Sebagai mana diutarakan oleh Wakil Koordinator Jaringan Kerja Penyelamat Hutan Riau (JIKALAHARI) sebagai berikut: 
"Rekomendasi pelepasan Hutan oleh Tim Terpadu mulai bekerja dari Tahun 2009-2012 bikin kajian atas rekomendasi pelepasan TGHK seluas 3,5 juta Hektar jaman Gubernur Riau Rusli Zaenal sebelumnya tetapi yang dilepas atas rekomendasi Tim terpadu 2,7 Juta Hektar. Setelah itu, SK tidak langsung terbit karena lama terundur dan tepatnya pada tahun 2014 tanggal 9 agustus keluarlah SK 673 tersebut sebagai buah hadiah hari jadi Provinsi Riau momennya. Ketika menyerahkan SK tersebut, Zulkifli Hasan mengusulkan jika masih ada lahan masyarakat yang belum diakomodir dalam SK dapat mengajukan revisi melalui Pemerintah Daerah. Akan tetapi muncul protes dikarenakan dari kementerian sekitar 1,6 Juta Hektar lebih sekian jadi hamper ada gap dengan rekomendasi Tim Terpadusekitar 1,1 Juta dari rekomendasi sebelumnya". (Okto Yogo Setyo Selaku Wakil Koordinatorv Jaringan Kerja Penyelamat Hutan Riau (JIKALAHARI).

Akibatnya, ada ruang-ruang kompromi yang disalah artikan oleh beberapa pihak ketika membahas proses usulan terkait revisi alih fungsi hutan. Sebagai mana diutarakan oleh Kepala Dinas Perkebunan saat itu, bahwa keluarnya aturan SK 673 didasari untuk dapat mengatur tata ruang kawasan hutan,akan tetapi prosesnya banyak menemui hambatan dan beberapa usulan dari daerah tidak semuanya dapat dilaksanakan. Seperti kutipan wawancaranya adalah sebagai berikut: "Persoalan mulai dari masalah ijin pelepasan kawasan hutan yang tidak tuntas sekian lama dari daerah hingga pusat yang tidak konsisten sebenarnya. Selain itu, Saya memang menerima mereka gulat dan salah satu pihak korporasi pada malam hari yang membahas lahan perkebunan mereka. Dikarenakan saya lakukan biasa pergi pagi dan pulang terakhir atau sampai malam untuk bekerja, maka karena itu saya dipanggil KPK". (Wawancara dengan Zulher selaku Kepala Dinas Perkebunan)

Penulis melihat aktor-aktor terlibat dari berbagai dimensi berdasarkan posisi jabatan dan wewenang, tujuan, keterkaitan hubungan dan motivasi tertentu dari kapasitas yang dimiliki oleh elit itu sendiri. Hal ini merupakan peran dari kelompok elit politik, elitekonom, elitsosial dan keterlibatan actor tertentu merangkap sebagai tokoh masyarakat.Seperti menyatakan pendelegasian tanggung jawab dari pimpinan ke oknum (agen), yang memiliki wewenang hukum, serta kewajiban resmi dan informal, untuk menggunakan wewenang, kapasitas, dan informasinya untuk mengejar kepentingan para pelaku (Della Porta dan Vannucci, 2012)

Berangkat dari korupsi usulan perubahan peta lahan melibatkan Annas Ma'amun selaku Kepala Daerah saatitu dan dugaan korporasi hingga birokrat yang memberikan kemudahan dalam memberikan informasi. Identifikasi tersebut diperlukan agar mampu menjelaskan dan memahami posisi elit yang ikut terlibat serta motivasi yang mendorong terjadinya tindakan korupsi.

Adapun salah satu kejanggalannya adalah usulan perubahan peta lahan ini sebagian tidak memenuhi hasil kerja tim terpadu. Hal tersebut menjadi temuan pada penelitian ketika usulan tim terpadu tidak dilaksanakan sepenuhnya. Seperti diungkapkan oleh Kepala Dinas Kehutanan saat itu, sebagai berikut:

"Oleh pusat diberi kita kesempatan untuk merehap sesuai SK 673, pihak Kementerian Kehutanan mengatakan $80 \%$ yang baru memenuhi dari hasil kajian terpadu, maka dari situlah SK tersebut keluar kalau ada yang mau diusulkan oleh masyarakat riau dan sifatnya yang memutuskan itukan Menteri dan barang kali ada yang mau diperbaiki silahkan usulkan. Karena ada sinyal seperti itu mulailah Pak Gubernur mengusulkan di luar dari hasil tim terpadu itu gitu yang diusulkan kami saat itu kepentingan publik, yaitu terkait airport di Rohil, jalan, candi muara takus mau di pugar (dikembangkan), kemudian diberi kesempatan kita revisilah dari jalan tol yang terpotong karena kawasan hutan".(Wawancara dengan Irwan Effendi selaku Kepala Dinas Kehutanan)

Timbulnya kebijakan revisi oleh pusat membuat sejumlah pemilik perkebunan kelapa sawit hingga korporasi besar ingin mengetahui perubahan peta lahan tersebut sebelum dipublikasi oleh Pemerintah Daerah saat itu. Bahwa Kepala Dinas Kehutanan saat itu member kembali keterangannya, 
ketika proses pembahasan revisi alih fungsi hutan dalam rancangan RTRW memang banyak yang menghubungi beliau untuk mengetahui hasil perubahan peta lahan Provinsi Riau. Dengan tegas beliau menambahkan penjelasannya sebagai berikut:

"Beliau (pak zulher sebagai Kepala Dinas Perkebunan) semangat mencari tau karena dorongan perusahaan karena menanyakan kebun perusahaan ini masuk atau ga, nah itu semangat dia menanyakan kesaya langsung. Akan tapi saya ga mau dan saya katakan itu bukan wewenang saya tetapi kerja Bappeda. Walaupun lampiran Peta Lahan tersebut itu memang saya pegang tapi nanti saya berikan ketika publikasi secara resmi dan itulah dengan gulat mereka gasekali atau dua kali runding itu (membahas perubahan peta lahan itu), waktu itu saya juga agak kurang ngehh sama mereka saat itu (kurang maksud tujuan mereka) melihat orang ini.”. (Wawancara dengan Irwan Effendi selaku Kepala Dinas Kehutanan)

Adanya ini siatif ingin mengetahui terlebih dahulu perubatan peta lahan walaupun sebetulnya boleh diakses oleh publik saat itu, peneliti menganalisa dan konfirmasi dengan beberapa narsumber terkait tranparan siperubahan peta lahan tersebut. Hal ini yang salah satu penyebab dan mengakibatkan terjadinya tindakan ilegal, dengan cara melakukan upaya kompromi agar bias mengamankan lahan dan memperluas usaha bisnis beberapa korporasi di Provinsi Riau.

Selain itu, pemetaan aktor ini memberikan gambaran realita dilapangan yang terjadi karena tidak menutup kemungkinan adanya aktor yang memiliki power sebagai patron dan turut serta menjadi broker dalam usulan perubahan peta lahan. Bahwa praktik korupsi yang terjadi menujukan ada pola hubungan kekuasaan mencoba untuk melakukan kompromi secara illegal atas revisialih fungsi hutan.

Revisi ini menjadi sebuah pola hubungan, dimana kekuasaan berpihak pada oknum atau actor tertentu sekaligus memanfaatkan sumber dayanya sebagai patron. Dengan kata lain permasalahan kebijakan terletak di mata para pelakunya (Darwin, 1999). Hal ini bukan rahasia umum ketika kekuasaan dan otoritas politik digunakan agar dapat memberikan peluang untuk meningkatkan bisnis. Sementara itu, keuntungan yang diperoleh nanti dari bisnis tersebut bias dipergunakan untuk memperluas pengaruh dalam setiap aktivitas politik.

Kebijakan revisi alih fungsi hutan ini sangat mengkhawatirkan, sejauh pengamatan peneliti ada diskursus yang berkembang di tengah masyarakat lokal terkait kecemasanakan kestabilan lingkungan. Hal tersebut akibat dari beberapa pelaku bisnis dengan berusaha melakukan upaya non prosedural sehingga bias menimbulkan terjadinya politik kartel yang dapat mengkooptasi kekuasaan.

Korupsi yang terjadi menujukkan ada interaksi dengan menyentuh struktur kelembagaan. Hal tersebut memperlihatkan suatu kondisi tatanan relasisosial yang terstruktur dalam hubungan dualitas (timbal balik) antara sang pelaku dan struktur (pimpinan-bawahan). Hubungan ini adalah dualitas yang menjelaskan fungsi sebagai sebuah aturan dan sumberdaya.Sebagai mana diutarakan oleh Tim Senarai sebagai Pemantau Hukum sebagai berikut:

Mengungkapkan bahwa salah satu birokrat bernama Cecep Iskandar Kepala Bidang Planologi Dinas kehutanan Provinsi Riau saat itu dan membuat peta yang akan diusulkan pada revisi kedua RTRW Riau. Peta tersebut yang dimasukkan beberapa daerah di luar dari usulan Tim Terpadu. Cecep Iskandar ketika dipersidangan mengungkapkan "Saya diperintah Pak Gubernur, Annas Maamun" katanya.Setelahnya Cecep Iskandar ditelpon Annas Maamun selaku Gubernur Riau saat itu untuk berkoordinasi dengan Gulat Medali Emas Manurung Selaku Ketua Apkasindo terkait lahan yang akan dimasukan kedalam usulan revisi RTRW Riau.Lahan yang dimaksud terletak di daerah Rokan Hilir dan Kuantan Singingi. Cecep Iskandar dipercaya oleh Annas Maamun mengantarkan langsung usulan revisi kedua RT RW Riau tersebut kekantor Kementerian Kehuatanan. Setibanya di Jakarta, cecep bertemu dengan Gulat dan memastikan bahwa lahannya sudah masuk kedalam usulan revisi RT RW Riau. Gulat memberi uang kepada Cecep sejumlah 26 juta 850 ribu rupiah. Saat ditanya hakim Cecep mengatakan“Kata Pak Gulat untuk jajan karena 
diberikan di tempat terbuka, saya tidak enak menolak. Maka saya ambil uang itu,"katanya begitu. (Suryadi dari Senarai selaku pemantau persidangan)

Cecep Iskandar menunjuklahan di Rokan Hilir milik Annas Maamun, lahan di Kuantan Singingi Gulat Manurung. Lahan-lahan tersebut dimasukkannya kedalam usulan revisi kedua RTRW Riau. Sebabatas perintah Annas Maamun dan melanggar ketentuan karena berada di luar usulan tim terpadu.

Peneliti juga mendapatkan informasi ada lahan di Rokan Hilir Annas Maamun, di Kuantan Singngi milik Gulat Medali Emas Manurung dari hasil persidangan. Bahwa lahan-lahan tersebut dimaksukannya kedalam usulan revisi kedua RTRW Riau sehingga melanggar ketentuan karena berada di luar usulan Tim Terpadu.Korupsi ini seolah-olah menjelaskan betapa kuatnya interaksi aktor yang memiliki kapasitas secara materi dan kekuasaan.

Hal ini sekaligus memperlihatkan budaya korupsi yang terjadi di dalam struktur merupakan pola hubungan struktur penguasaan atau dominasi yang mencakup skema penguasaan atas orang (politik) dan barang ataupun berbentuk apapun. Mekanis mestruktur yang mengalami kerusakan moral melahirkan korupsi politik ini menjelaskan maksud dari motivasi dan tindakan illegal tersebut.Seperti diungkapkan oleh Deputi WALHI sebagai berikut:

"Kenapa korupsi itu sudah terstruktur dan terencana, karena yang mempunyai perusahaan ini sudah punya kaki di masing-masing pemerintahan, katakanlah banyak pembinis saat ini jadi pejabat terutama di Provinsi Riau dan mereka tidak bias dipungkiri melanggengkan bisnis mereka dengan politik" (Fandi Rahman selaku Deputi WALHI).

Korupsi ini tidak hanya sekedar tindakan suapakan tetapi terbentuknya pola interaksi antar aktor yang bersifat patronase. Temuannya, pertama korupsi yang ditopang oleh jaringan elit politik dan bisnis, kedua kontestasi actor dalam perubahan kawasan hutan terkai trancangan rencana tata ruang wilayah (RTRW) Provinsi Riau dan ketiga kepentingan electoral kepentingan penguasaan sumber daya alam (SDA).

Di samping itu, peneliti juga mendapatkan hasil lain dilapangan, yaitu aktor birokrasi yang tidak mau terlibat dalam penyelewengan tugas terkait korup secara kelembagaan. Hal ini bagi beberapa birokrat lebih baik diam dari pada harus membuat heboh sehingga terekspos buruknya tindakan illegal yang dilakukan oleh salah satu oknum. Terutama jika penyimpangan dilakukan oleh mereka yang punya posisi kuat dan ketakutan ada kemungkinan mengancam karir sebagai birokrat. Seperti bias memindahkan dan memutasi yang membuka perilaku korup tersebut atasan ataupun instansi tempat birokrat tersebut bekerja.

Pada akhirnya baik birokrat yang tidak terlibat maupun ikut terlibat dalam melakukan penyimpangan keduanya dapat diakatatkan sama-sama kehilangan kemampuan untuk mengedepankan integritas dan kejujuran dalam melaksankan tugasnya. Oleh sebab itu cenderung ada beberapa pejabat publik yang "korup"dalam kebanyakan system politik yang tidak secara luas diyakini menjadi korup tetapi ada makna pembusukan aturan perilaku moral atau konstitusional (Henheimideer, 2007:5)

Kemudian kembali pada proses usulan perubahan peta lahan ini berkorelasi dengan kepentingan pembisnis besar terutama bisnis perkebunan kelapa sawit yang dominan di Provinsi riau. Kebijakan ini walaupun dasarnya member mandat demi kepentingan kelompok petani sawit yang lahannya belum terakomodir tetapi menjadi celah penyelewangan oleh oknum pejabat dan segelitir aktor berkepentingan. Hal tersebut menciptakan solusi bagi pembisni suntuk kejelasan lahan usaha mereka, akan tetapi sadar atau tidak turut menciptakan korupsi baru dan mengarah kepada kerusakan dengan salah merespon kebijakan revisi tersebut. 


\section{KESIMPULAN}

Kebijakan revisi alih fungsi hutan ini dalam prakteknya memiliki peranan besar terhadap pembentukan tata ruang di Provinsi Riau. Revisi tersebut justru sebaliknya memperlihatkan tarik menarik kepentingan yang memberikan keleluasaan bagi kelompok bisnis untuk mengembangkan bisnisnya dan sebagai imbalannnya digunakan untuk mendapatkan penghasilan secara ilegal.

Usulan perubahan peta lahan ini merespon mandat dari Surat Keputusan Menteri SK No 673 Tahun 2014 Tentang Perubahan Peruntukan Kawasan Hutan Menjadi Bukan Kawasan Hutan, sengaja atau tidak hadirnya kebijakan revisi tersebut terjadi penyelewengan kewenangan dalam prakteknya. Temuan yang tidak memenuhi hasil kajian tim terpadu dan kompleksitas proses pembahasan kebijakan revisi tersebut menghasilkan kekacauan dalam menyembunyikan praktek politik korupsi politik. Korupsi tersebut dapat menjadi sistemik dari tingkat atas sampai bawah system pemerintahan yang dijalan kanapa bila polemik penetapan RTRW masih berlanjut.

\section{SARAN}

Korupsi secara tidak langsung bias menimbulkan distorsi di dalam sektor publik dengan pengusaan lahan terhadap bisnis yang dikembangkan dan mengalihkan investasi publik.Dalam persoalan ini pentingnya memiliki political will dari sosok seorang pemimpin yang berintegritas dalam merespon segala permasalahan kebijakan revisi alih fungsi hutan di Provinsi Riau. Maka situasi seperti ini seharusnya memberikan proteksi kepada kepentingan politik dan bisnis tanpa ada keberpihakan pada salah satu kelompok.

Berbagai fakta korupsi tersebut sesungguhnya menjadi bukti bahwa korupsi berpotensi dilakukan oleh siapa saja yang ikut terlibat. Hal ini sekaligus menunjukkan betapa korupsi tidak saja menjadi persoalan hukum, melainkan juga merupakan persoalan mentalitas individu seseorang yang diberikan mandat sebagai pemimpin.

\section{DAFTAR PUSTAKA}

[1] Ackerman, Susan Rose (2006). Korupsi Pemerintahan, Sebab Akibat Dan Reformasi. Jakarta: Pustaka Sinar Harapan.

[2] Barrow, E., Clarke, J., Grundy, I., Jones, K-R., \&Tessema, Y. (2002). Analysis of stakeholder power and responsibilities in community involvement in forest management in Eastern and Southern Africa (No. 9). IUCN.

[3] Creswell, John W. (2016). Research Design: Pendekatan Metode Kualitatif, Kuantitaif dan Campuran. Yogtyakarta: Pustaka Pelajar.

[4] Darwin, Muhajir. (1999). Analisa Kebijaksaan Publik. Yogyakarta: Hanindita Graha Widya.

[5] Heidenheimer, Arnold J and Johnson, Michael (eds.) 2007, Political Corruption; Concept and Context, Transaction Publishers, New Brunswick.

[6] Lexi, J. M. (2006). Metode Penelitian Kualitatif. Bandung: Remaja Rosda Karya. 
[7] Syahadat, E., \&Subarudi, S. (2012). Permasalahan Penataan Ruang Kawasan Hutan Dalam Rangka Revisi Rencana Tata Ruang Wilayah Provinsi. Jurnal Analisis Kebijakan Kehutanan, 9(2), 131-143.

[8] Brockhaus, M., Obidzinski, K., Dermawan, A., Laumonier, Y., \& Luttrell, C. (2012). An overview of forest and land allocation policies in Indonesia: Is the current framework sufficient to meet the needs of REDD+? Forest Policy and Economics, 18, 30-37.

[9] Della Porta, D. \&Vannucci, A. (2012). Political Corruption. The Wiley-Blackwell Companion to Political Sociology. 1st Edition. Blackwell Publishing Ltd.

[10] Myers, R., \&Ardiansyah, F. (2015). Siapa yang memegang kekuasaan dalam tata gunalahan? Dampaknya bagi REDD+ di Indonesia (Vol. 113). Bogor: CIFOR.

[11] Maryudi, A. (Eds.). (2015). The context of natural forest management and FSC certification in Indonesia (Vol. 126): The political of forest land-use, the timber sector, and forest certification (pp. 9-34). Bogor: CIFOR.

[12] https://acch.kpk.go.id

[13] http://senarai.or.id/ 